\title{
GENRE SPECIFICS OF ADVENTURE PROSE IN LITERARY STUDIES OF THE URAL-VOLGA REGION
}

\author{
Marina P. Savirova ${ }^{* 1}$, Nadezhda I. Yakimova ${ }^{2}$ \\ ${ }^{1}$ Assoc. Prof. Dr., I.N. Ulyanova Chuvash State University, RUSSIA, marina.savirova@yandex.ru \\ ${ }^{2}$ Assoc. Prof. Dr., I.N. Ulyanova Chuvash State University, RUSSIA, yakimovanadya@yandex.ru \\ ${ }^{*}$ Corresponding Author
}

\begin{abstract}
The history of world literature presupposes the coverage of those phenomena and processes that bring together various national literatures, certain groups of them [1]. The discovery of such sides will help to better and deeper understand both the composition and the plot features of adventure genres.

The poetics of adventure prose has been sufficiently studied in many national literatures. Nevertheless, to date, the issues in the comparative perspective remain unresolved. In this sense, it is important to take into account the changed attitudes towards such areas of Chuvash fiction as fiction, detective, adventure, which have become very fascinating for modern readers. In terms of genre, they are short stories, novellas and novels. They are united by the commonality of the characters' lives, conflict situations and circumstances, ways of plotting.

The article is devoted to the problem of studying adventure genres in literary studies of the Ural-Volga region, the manifestation of elements of adventure in artistic practice, the typology of the plot and the typology of heroes are investigated, attention is also paid to their plot-compositional features, to certain features of the hero, the nature of situations and circumstances.
\end{abstract}

Keywords: analysis, adventure genre, plot and compositional features, detective story, short story, novel.

\section{INTRODUCTION}

The article draws attention to the specifics of genre-forming factors of adventure literature of the Ural-Volga region, and also fills the gap in understanding the national characteristics of adventure genres. Comparative analysis in different literatures is used, which helps to find not only related and similar features, but also features that distinguish them from each other. This helped to identify the collision, plot and compositional properties of a single literature.

\section{MATERIALS AND METHODS}

Comparative and historical-typological analyses were used as scientific research methods, which allowed analyzing the originality of adventure prose, its genre specifics, features of its plot and composition. This method allows us to find out to what extent the adventures included different stylistic techniques, how they 
were combined in the works with the features and properties of other literary styles.

Methods such as analysis and comparison of texts of works of art, comprehension of literature as an artistic reality, the formation of the spiritual world of man on this basis, [2], [3], [4] they became the leading ones during the course of this study.

\section{RESULTS}

The adventure genre is very widely represented in world literature. Readers of any country are well known and familiar with the stories about Sherlock Holmes by the English novelist A. Conan Doyle. The French writer J. Simenon created a wonderful image of Commissar Magre, the works of Agatha Christie, the adventurous novels of $A$. Dumas-father, etc. are very popular among readers. These genres arose a long time ago, back in the XVIII century. At this time, as the research of A.Yu. According to Narkevich, "two types of plot composition were known: a novel built on an alternation of unexpected events, by chance subjecting the heroes to all sorts of trials and disasters or bringing them sudden deliverance." "In the novel of the second type $\langle\ldots\rangle$, behind the visible circle of events, another series of mysterious forces (a person, fate or a ghost) is hidden, invisibly guiding the course of action and the denouement: chance loses power, the plot acquires a deep unity" [5]. This shows that even when such works were first published, they began to be created on unexpected events. They (exceptional events) were created to test a person's character by "all kinds of tests." In the novels of the second type, the person depicted also did not occupy the main place in the plot, he was influenced by "fate, providence"; the denouement depended "on mysterious forces", so the main place here was occupied by the plot. In the future, such a genre did not forget its main features and properties, only deepened them. "In the nineteenth century, literature is composed in which the motive of adventure acquires a self-sufficient character; adventure becomes the main subject of the image and the dominant in the construction of images of heroes." "It is especially characterized by the general properties of adventure literature - dynamism, sharpness of the plot, replete with riddles, exceptional situations, sudden turns of action" [5]. These quotes show a general, preliminary picture of the adventure genre. Basically, literature of this kind developed in the West, these are the works of J. Verne, G. Emard, A. Dumas-father, E. Xiu and others. In Soviet literature, books by V. Kaverin, A. Green, I. Efremov, B. Polevoy, A. Rybakov and some other authors are known. There are masters of such prose in Chuvash literature. This is L. Agakov, D. Kibek, G. Luch, S. Aslan, A. Grigoriev, V. Petrov, R. Yarandai, N. Maksimov, G. Krasnov, etc.

And in Chuvash literature, adventures began to be written according to the rules that had been worked out by previous centuries. "The plots-" as can be understood from the words of A. Narkevich- "were saturated with persecution, kidnappings, transitions from danger to deliverance, unexpected catastrophes... Adventure literature is characterized by a sharp psychological contrast between positive and negative characters" [5]. The positive characters were idealized, the negative ones were shown to be exaggeratedly bad, vile and disgusting. The tasks of showing the psychological experiences of the characters here occupy a secondary place. Critics often considered such works weak, and began to look for flaws in adventure works. By this they showed that they did not take into account the laws of adventures and detectives. Time has shown that these searches were not quite correct and true, they did not take into account that each writer could have his own views on the life he portrayed [6], [7].

Very often the adventure itself (chases, pursuits, dynamics itself) is closely connected in the work with the detective (search, gradual solution of the mystery). Adventure events sometimes give way to detective, detective - adventure; this helps to develop the plot better, to interest the reader, to better build the composition of the work. Adventure is a very broad genre, it has more "over-genre" (A. Vulis) traits. In this case, the detective is just one type of adventure, and these genres have a lot of close, related.

The world experience in national literature is not directly repeated, each literature, each particular writer has its own secrets and its own ways of developing national adventure literature and its poetics.

One of the most poorly studied problems in literature in Chuvash literature) is the originality of adventure prose, its genre specifics, the peculiarities of its plot and composition. As A.Y. Narkevich says, the study of adventure literature "was hindered by critics of the RAPP times, who declared it "a great Evil", and its "morality, perception of the world and thinking through bourgeois." M. Gorky, who "positively evaluated" the adventure books of many authors, actively defended it at the time [5]. That is the only reason why books from the series "Libraries of Science Fiction and Adventure", "Libraries of Adventure", "World of Adventure", etc. began to appear in the country.

The study of critical literature shows that in the Volga literatures (especially in the Mari, Mordovian), the situation is not entirely unfavorable. To make big generalizations, it is necessary first to study the experience of detectives and adventures, to understand the originality of their poetics. And only then will it be possible to 
draw any conclusions. In Chuvash literary studies, for example, detectives and adventures were studied on the examples of works of the $30 \mathrm{~s}, 50 \mathrm{~s}$. During this period, according to some critics, certain features of adventure, criminal, heroic-adventure prose were studied.

Comparative study of the subject is not enough [9], a historical approach to the problem is also needed. This method allows you to find out to what extent the adventures included different stylistic techniques. In critical articles by V.Ya. Kanyukov (1971; 1974), the Mari researcher K.K. Vasin (1980), the Mordovian critic N.I. Cherapkin (1969), the writer, following the path of creating detective-adventure works, follows an easy path, builds a plot, loading it with events. In this case, the characters of the heroes and the historical cause of the events are poorly revealed, the course of the social history of a particular country is poorly studied. Based on this, the analysis of the works was done one-sidedly.

The story of the Mari prose writer Chavain "The Fugitive" tells about a chain of adventure events: 1) the hero became a "victim of hunger"; 2) "He climbs into the barn of a fist"; 3) "He is thrown into prison"; 4) "He runs into the forest"; 5) "With crying tells the story of his sad fate", etc. [8]. According to the Mordovian critic, the hero of the story is weak and inactive. Not a little attention is paid to the fact that such plots were often found in Mari folklore. Therefore, the scientist came to the conclusion that the writer showed the formation of the character of a fighter, he did not outline the environment and circumstances characterizing his change. However, in such cases, according to the researcher, "it is not by the will of circumstances that a person becomes an adventure hero." Here "the authority of the initiative is strong" [10], and then the plot is already developing to justify this "beginning". Showing the historical situation would be associated with the description of the opposing enemies, the enemy environment. Then the folklore-adventure plot would have lost a lot, the hero would have to be completely different. Cherapkin emphasizes: "the story resembles poetic prose in style- it is a story about a human tragedy" [8]. The Fugitive has a time of crisis, which is exactly what Chavain reveals.

It is believed that the tasks of creating a character require that the novelist use the ways of psychological disclosure of a person's emotional experiences. In this case, it is very difficult to rely on the rapid change of events, here the disclosure of the character of the hero is optional. M.A. Urnov, for example, considering the adventures of Robinson Crusoe (D. Defoe), indicates the "insensitivity", "impartiality" of the writer. "Thus, Defoe's 'insensibility'," he says, "is like Hamlet's 'madness', methodical. Like the "authenticity" of Robinson's "Adventures", this "insensibility" is sustained from beginning to end, consciously created" [11]. Many events shown by such a writer can create the impression that the plot is loaded. But, Urnov believes, "with the help of description, replicas, dialogue, internal monologue," the writer connects alternating events, unites "everything in the integrity of a moving image."

In adventure stories and novels, the main role is played by the moral characteristics of the characters. Therefore, the opinion that the plot is loaded, that the characters are weak, is due to the fact that critics did not know the laws of adventure genres well enough.

The above-reviewed story "The Fugitive" [8] shows that the plot should be dynamic, the writer stops his attention on the crisis state of the hero's soul. This helps him to create "the authority of the initiative."

One can easily guess that such criticism wanted to direct all fiction only along one path - showing class clashes, the course of the history of society. The plot was often created on superficial events, on their rapid alternation. Critical literature considered this the norm and at the same time distrusted the fact that sometimes the course of events turned in the direction of the detective and adventure.

In the novel "Red Army Soldiers" by A. Tagirov, different characters are drawn: the ardent agitator Gilyazhi; the head of the enemy regiment, Zaki Validov; Magafur, who recently became rich and therefore opposed the Reds, etc. Magafur "came under the leadership" of Validov because he wanted to preserve the recently accumulated wealth, it is "on such as him that Validov relies in his adventurist policy" [12]. Magafur is now able to speak out against his brother. Revealing the shortcomings of the novel, the researcher notes that the novel begins with "pure documentary chronicling" [12]. That is, the events of the Civil War became the basis of the novel, the fact that convinced Bolsheviks and adventurous commanders and commanders participated in it. In this case, the writer paid great attention to the plot, he sometimes had to see not so much the hero "man, it was important to see the movement of history, the collision of opposing forces" [12]. The hero immediately willy-nilly began to play a secondary role.

Literary critics have found those features that are often found in adventures. These are: 1) the techniques of folklore idealization of heroes (Vasin); 2) the fact that the narrative depends on the plot (Cherapkin); 3) in the plot of his (Chavain) character has already received what "he desperately" needs; 4) the constant deployment of ready-made ideas is necessary to become a characteristic of the hero. Moreover, the full 
description is given to him already at the beginning of the story and the writer only deepens it. You can make sure that such heroes show us what is prepared with a ready-made plot. This technique is called "amplification" (G.I. Fedorov).

The consciousness of historical duty is connected with the process of character formation. In this case, the character should develop, acquire a variety of features. From the point of view of developing characters, the story of the Chuvash prose writer V. Ignatiev is evaluated. The novel "The Cursed Day", as it may seem at first, should give the character development and psychological changes of the artist Tagaev. However, anecdotal events occur one after another: 1) the hero can't wait for the driver of the car, 2) drunks gathered in the dining room spoil his mood, 3) someone spills sticky liquid on him on the bus, etc.D. Tagaev wants to hide from such abominations in his workshop, he paints images of beautiful women in body and soul there and thereby saves himself. The researcher correctly believes that the plot is simplified. And adventure stories need to be developed deeply, from all sides [13]. He finds the same sides in L. Agakov, who wrote the novel "The Most Expensive". He sees the writer's shortcomings in the fact that Agakov was more interested in ordinary facts, but not in the artistic truth of the plot being developed. In these facts, allegedly taken directly from life, the main features of the adventures were lost [13]. In adventure genres, events should be saturated with more meaning than here. One can recall the words of $A$. Vulis, "An adventure in literature is a combination of events", not factographically, but "metaphorically reproducing real life" [10].

The events in the story are also anecdotal in nature: at the same time, the writer shows an irreconcilable purity of soul in him, he laughs at him. In the story of V. Ignatiev, as in the stories of Chavain, there is also a romantic pathos, but this romance is also ironic. As events occur, facts and factual cases begin to take on a different meaning. The main thing here is that in the course of events there is some secret that needs to be revealed. All this suggests that the boundary between fact and metaphor, between a light genre and serious literature is not just conditional. Eg: "Don Quixote" by M. Cervantes and "Gargantua and Pantagruel" by F. Rabelais, "Notes of the Pickwick Club" by Charles Dickens, "Crime and Punishment" by F. Dostoevsky, "Les Miserables" by V. Hugo, "The Moment of Truth" by V. Bogomolov reveal to the reader one side adventurous, adult and "the second, serious: psychological, satirical, philosophical" [10]. All this suggests that adventures by their nature are very wide and deep [14].

Talking about the early prose of the Mari, N.I. Cherapkin in Chavain's "The Fugitive" finds that a person has become a victim of arbitrariness, this, in his opinion, is "exactly a fugitive", and not an active fighter with firm political beliefs, a plot painted with romantic colors is made of this [15]. The researcher considers such a trait to be a big drawback, the "limitations" of the author. According to the Mordovian critic, this depends on the fact that "writers of emerging literatures, not yet possessing a wide horizon of historical knowledge, pushed aside acute social conflicts" [15].

Thus, the poetics of adventure is used by writers on a variety of materials, in a variety of facts. Ready-made plots are exceptionally rich in possibilities of change based on both folklore and literary material, etc. [2]. The history of literature and its rich experience are present here.

\section{CONCLUSION}

The state of knowledge of adventure literature makes it possible to identify phenomena and processes that bring together various national literatures, their various forms. Considering them helps to better understand the features of adventure genres.

In recent years, a certain interest in the comparative study of genres has increased in Chuvash literary studies [3], [6]. [16], [17]. In this regard, both the specific features of the hero and the problems of the inner world of a person in adventure genres still need more serious research. Ready-made plots are especially rich in development opportunities based on both folklore and literary material.

\section{REFERENCE LIST}

1. Khrapchenko, M.B. (1981). The creative individuality of the writer and the development of literature. Collected works. M.: Art. lit. Vol. 3. 432 p.

2. Savirova, M.P. (2005). Artistic originality of the Chuvash adventure prose: dis. for the degree of Candidate of Philological Sciences. Cheboksary. $174 \mathrm{p}$.

3. Ermakova, G.A., Yakimova, N.I., Savirova, M.P. (2019). Reflections on the style of G.N. Aigi and Sh. 
Baudelaire // Ashmarin readings. Collection of materials of the XI International Scientific and Practical Conference. Cheboksary: Chuvash Publishing House. un-ta. P. 93-96.

4. Yakimova, N.I., Ermakova, G.A. (2018). Proverbs and sayings in children's stories by I.Ya. Yakovlev // National languages and literatures in multicultural conditions: collection of scientific papers. Cheboksary: Publishing House of the Chuvash State Pedagogical University named after I.Ya. Yakovlev. P. 146-149.

5. Narkevich, A.Yu. (1968). Adventure literature. Brief literary Encyclopedia. Moscow: Vol. 5. Stb. P.973-974.

6. Savirova, M.P. (2008). Formation and development of Chuvash adventure prose: a textbook. Chuvash State University named after I.N. Ulyanov. Cheboksary: Chuvash Publishing House. un-ta. 139 p.

7. Savirova, M.P. (2016). Formation of adventure genres in national literature // Ashmarin readings, proceedings of the $\mathrm{X}$ International Scientific and Practical Conference. Cheboksary: Chuvash Publishing House. un-ta. P. 56-58.

8. Cherapkin, N.I. (1973). Tributaries. M.: Sovremennik. 198 p.

9. Yakimova, N.I. (2007). Somatic phraseological units of the Chuvash language: the experience of comparative research with Tatar, Bashkir, Turkish languages // abstract of the dis. ... candidate of Philological Sciences / Chuvash State University named after I.N. Ulyanov. Cheboksary. 25 p.

10. Vulis, A.Z. (1986). In the world of adventure: the poetics of the genre. M.: Soviet writer: $384 \mathrm{p}$.

11. Urnov, M.V. (1986). Milestones of tradition in English literature. Moscow: Art. lit. 384 p.

12. Vakhitov, A.H. (1978). Bashkir Soviet novel. Moscow: Nauka: 160 p.

13. Artemyev, Yu.M. (1979). Problems and characters in the works of Chuvash prose. Problems of the creative method in Chuvash literature. Cheboksary. P. 61-97.

14. Savirova, M.P. The artistic originality of the Chuvash adventure prose // autoreferat dis. ... candidate of Philological Sciences / Chuvash State University named after I.N. Ulyanov. Cheboksary, 2005. 20 p.

15. Cherapkin, N.I. (1969). In a fraternal community. Saransk: Mord. kn. ed. 384 p.

16. Yakimova, N.I. (2015). National-cultural features of phraseological units of related languages // In the collection: Problems of culture in modern education: global, national, regional-ethnic Collection of scientific articles. Edited by G.L. Nikonova, A.V. Nikitina. P. 188-192.

17. Yakimova, N.I. (2014). Some approaches to the study of phraseology by thematic and semantic fields // Ashmarin readings: collection of materials of the IX International Scientific and Practical Conference. Cheboksary: Chuvash Publishing House. un-ta. P. 157-162. 